\title{
INFLUENCE OF WAVELENGTH OF LIGHT ON GROWTH, YIELD AND NUTRITIONAL QUALITY OF GREENHOUSE VEGETABLES
}

\author{
Margit Olle ${ }^{1, \#}$ and Ina Alsina ${ }^{2}$ \\ 1 Estonian Crop Research Institute, J. Aamisepa 1, Jogeva alevik, 48309, ESTONIA \\ ${ }^{2}$ Institute of Soil and Plant Sciences, Latvia University of Life Sciences and Technologies, 2 Lielā Str., Jelgava, LV-3001, LATVIA \\ \# Corresponding author, margit.olle@gmail.com
}

Contributed by Ina Alsiṇa

\begin{abstract}
All previous reviews of research on light-emitting diodes (LEDs) have been focused on how different light spectra generally influence plant yield and quality. There are no or almost no reviews on the effect of spectra on sugars or pigment concentration, or yield and growth etc. The role of visible light in food production, as in agriculture and horticulture, is obvious, as light drives photosynthesis, which is crucial for plant growth and development. Solid state lighting using LEDs represents a fundamentally different technology from gaseous discharge-type lamps currently in use. LEDs are important lamp types because the concentration of the light spectrum they emit can be changed to provide plants at various developmental stages with the light spectrum needed. A great deal of studies have been done on the effect of wavelengths of light on growth, yield and nutritional quality of greenhouse vegetables. However, little is known about the mechanisms by which the spectra affect sugar and pigment concentration, and yield, and growth. This article provides a list of how spectra influence the yield, growth, and nutritional quality of greenhouse-grown vegetables. Based on the given information we can conclude that blue, green, and red light are the main light colours that influence positively plant yield, growth and nutrient quality. Sometimes in specific situations, some other light colours are also beneficial, like far red light, orange light and UVA light. Future work on light colour manipulation has potential for producing lamps and greenhouse covers that better support plant yield, growth, and nutrition.
\end{abstract}

Key words: plants, LEDs, colour, yield.

\section{INTRODUCTION}

The role of visible light in food production, as in agriculture and horticulture, is obvious, as light drives photosynthesis, which is crucial for plant growth and development. However, less recognition is given to its usefulness in other aspects of food processing. Low quantities of light can maintain postharvest quality of several species of crops by mitigating senescence, and improving phytochemical and nutritional quality (D’Souza et al., 2015).

Solid state lighting using light-emitting diodes (LEDs) represents a fundamentally different technology from the gaseous discharge-type lamps in current use in horticulture (Morrow, 2008). Light-emitting diodes represent a promising technology for the greenhouse industry, which has technical advantages over traditional lighting sources, but is only recently being tested for horticultural applications (Olle and Virsile, 2013).

Testing of LEDs began in the United States in the late 1980s, and in the mid-1990s high output LEDs became available (Morrow, 2008). Horticultural lighting utilising light-emitting diodes (LEDs) was introduced to the general public in the first few years of the $21^{\text {st }}$ century. Since then, improvements in technology and pricing have made LED lights a viable alternative to the traditional and very effective High Intensity Discharge (HID) systems, while using only about $35 \%$ of the electricity required by HID lights (Anonymous, 2012).

Light is the sole source of energy for plant growth and development. Light is just one portion of the electromagnetic spectrum (Ryer, 1998). Terrestrial sunlight is considered to 
consist of ultraviolet (UV), visible (light) and infra-red light. The wavelengths of UV radiation (UVR) lie in the range of 100-400 nm; UV light is further subdivided into: UVA (ultraviolet A radiation, 315-400 nm), UVB (ultraviolet $B$ radiation, $280-315 \mathrm{~nm}$ ), and UVC (ultraviolet $C$ radiation, 100-280 nm) (Anonymous, 1992). Visible light ranges from low blue to far-red with wavelengths between 380 and $750 \mathrm{~nm}$, although this varies between individuals. The region between 400 and $700 \mathrm{~nm}$ is used by plants to drive photosynthesis and is typically referred to as Photosynthetically Active Radiation (PAR) (Anonymous, 2012).

Capabilities controlling spectral composition and high light output, with little radiant heat, make this technology potentially one of the most significant advances in horticultural lighting since the development of HID lamps (Morrow, 2008).

The LEDs have many benefits (Morrow, 2008). They allow wavelengths to be matched to plant photoreceptors to provide optimal production and influence plant morphology and composition. As they are solid-state devices, LEDs are easily integrated into digital control systems, facilitating special lighting programmes such as "daily light integral" lighting and sunrise and sunset simulations. They are safer to operate than current lamps because they do not have glass envelopes, or high touch temperatures, and they do not contain mercury. These systems progressed from simple red-only LED arrays using the limited components available at the time to high-density, multicolour LED chip-on-board devices. As light output increases while device costs decrease, LEDs continue to move toward becoming economically feasible for even large-scale horticultural lighting applications.

The aim of this review was to examine the wavelengths of light that affect growth, nutritional quality, and yield of greenhouse grown vegetables.

\section{OVERVIEW OF DIFFERENT LIGHT RECEPTORS AND THEIR PHYSIOLOGICAL ROLE}

Plants have pigment systems that capture radiant energy in different regions of the electromagnetic spectrum. For example, photosynthetically active radiation (400-700 nm) captured by chlorophyll pigments provides the energy for photosynthesis, the process by which plants combine carbon dioxide and water to produce oxygen and carbohydrates. Carbon assimilated during photosynthesis provides the energy to sustain life on earth (Rajapakse et al., 1999).

Light also acts as a signal of environmental conditions surrounding the plants. Photoreceptors act as signal transducers to provide information that controls physiological and morphological responses. Through these pigments, plants have the ability to perceive small changes in light composition for initiation of physiological and morphological changes. This ability of light to control plant morphology is independent of photosynthesis and is known as photomorpho- genesis. In photomorphogenesis, photons in specific regions of the spectrum are perceived by the photoreceptors present in smaller quantities. Known photomorphogenic receptors include phytochrome (the red and far-red light sensor that has absorption peaks in red and far-red regions of the spectrum, respectively) and "cryptochrome" (the hypothetical UV-B and blue light sensor) (Rajapakse et al., 1999).

Phytochrome is the most intensively studied sensory pigment that controls photomorphogenesis. Phytochrome is capable of detecting wavelengths from 300 to $800 \mathrm{~nm}$ with maximum sensitivity in red $(\mathrm{R}, 600$ to $700 \mathrm{~nm}$ with peak absorption at $660 \mathrm{~nm}$ ) and far-red (FR, 700 to $800 \mathrm{~nm}$ with peak absorption at $730 \mathrm{~nm}$ ) wavelengths of the spectrum (Rajapakse et al., 1999).

The relationship between light and plant growth can be demonstrated by exposing leaves to various colours of light. Light supplies the power to carry out photosynthesis, the food-making process in leaves. However, the spectrum of light most utilised by a leaf is limited to three distinct colours: red, blue, and yellow. For example, leaves appear green because green is the colour most leaves reflect rather than absorb and use.

\section{FOREWORD}

Far red light increases total biomass (Lee et al., 2016; Pinho et al., 2017), while at the same time increases plant elongation (Stutte et al., 2009) and decreases pigment concentration of plants (Li and Kubota, 2009). As plant elongation and decrease in pigment concentration are not desirable, this increase of biomass is not very advantageous.

Red light benefits reproductive growth (Li et al., 2012), increases tomato yield ( $\mathrm{Lu}$ et al., 2012), reduces nitrate concentration (Samuoliene et al., 2011) and increases vitamin C concentration (Bliznikas et al., 2012) in plants. As red colour of light increases yield by decreasing nitrate content and increasing C-vitamin content, and considering that both factors are highly desirable, then this colour has big potential use in plant production.

Orange light accelerates growth of transplants (Brazaityte $e t$ al., 2009), and therefore this light colour is also desirable in plant production.

Green light promotes growth (Johkan et al., 2012), reduces nitrate concentration (Samuoliene et al., 2012d) and increases saccharide concentration (Samuoliene et al., 2012d) of plants. Green light also has positive effect on vitamin C concentration (Samuoliene et al., 2012b) of plants. This colour of light contributes only to desirable factors in plant production and also has big potential use in plant production.

Blue light results in compact plants (Sergejeva et al., 2018). Blue light benefits vegetative growth (Li et al., 2012). Blue light increases pigment concentration (Sergejeva et al., 2018 ) in plants. The concentration of vitamin $\mathrm{C}$ is greatest 
under blue light (Li et al., 2012). This colour of light contributes to desirable factors in plant production and also has big potential use in plant production.

Like all living organisms, plants sense and respond to UV radiation, both the wavelengths present in sunlight (UV-A and UV-B) and the wavelengths below $280 \mathrm{~nm}$ (UV-C). All types of UV radiation are known to damage various plant processes. Such damage can be classified into two categories: damage to DNA (which can cause heritable mutations) and damage to physiological processes (Stapleton, 1992). UVA light can have also positive effects on plants, such as increase of anthocyanin concentration in baby leaf lettuce (Li and Kubota, 2009). However, UV radiation is rarely used in plant production.

\section{GROWTH}

Additional and supplemental lighting refers to all spectra applied in experimental or production conditions. Greenhouse vegetable growth is influenced by light colour (Table 1). Far red lighting increases growth of lettuce (Lee et al., 2016; Pinho et al. 2017). It elongates leaves in baby leaf lettuce (Li and Kubota, 2009), red lettuce (Lee et al., 2015) and in red leaf lettuce (Stutte et al., 2009) resulting in taller plants (Brown et al., 1995). Additional red light was observed to delay or inhibit transition to flowering in basil (Tarakanov et al., 2012). Red light induced upward or downward leaf curling in tomato (Ouzounis et al., 2016). Orange light accelerated growth of cucumber transplants (Brazaityte et al., 2009). Additional green light accelerated

THE EFFECT OF LIGHT COLOUR ON GROWTH OF GREENHOUSE VEGETABLES

\begin{tabular}{|c|c|c|c|}
\hline Plant & Effect on growth & Light colour & Reference \\
\hline Lettuce (Lactuca sativa L.) 'Frillice Crisp' & $\begin{array}{l}\text { Addition of far red light increased leaf area index } \\
\text { Faster growth may have caused decrease in dry } \\
\text { weight content by } 27 \% \text { and } 7 \% \text {, respectively }\end{array}$ & Far red $700-850 \mathrm{~nm}$ & Pinho et al., 2017 \\
\hline $\begin{array}{l}\text { Lettuce (Lactuca sativa } \text { L.) 'Sunmang' seedlings } \\
\text { from } 16 \text { days-old }\end{array}$ & Improved shoot and root growth & Far red $700-850 \mathrm{~nm}$ & Lee et al., 2016 \\
\hline Baby leaf lettuce (Lactuca sativa L.) 'Red Cross' & Increased stem length and leaf length & Far red $700-850 \mathrm{~nm}$ & Li and Kubota, 2009 \\
\hline Red leaf lettuce (Lactuca sativa L.) 'Outeredgeous & Leaf elongation & Far red $700-850 \mathrm{~nm}$ & Stutte et al., 2009 \\
\hline $\begin{array}{l}\text { Sweet pepper (Capsicum annuиm L.) 'Hungarian } \\
\text { Wax' }\end{array}$ & $\begin{array}{l}\text { Addition of far-red radiation increased plant height } \\
\text { and greater stem mass more than red LEDs alone }\end{array}$ & Far red $700-740 \mathrm{~nm}$ & Brown et al., 1995 \\
\hline Tomato (Solanum lycopersicum) genotypes & $\begin{array}{l}\text { Upward or downward leaf curling in all genotypes in } \\
\text { the } 100 \% \text { red treatment }\end{array}$ & Red $620-700 \mathrm{~nm}$ & Ouzounis et al., 2016 \\
\hline $\begin{array}{l}\text { Indian mustard (Brassica juncea L.), } \\
\text { Basil (Ocimum gratissimum L.) }\end{array}$ & Delayed or inhibited plant transition to flowerin & Red $620-700 \mathrm{~nm}$ & Tarakanov et al., 2012 \\
\hline Transplants of cucumber 'Mandy' F1 & Accelerated growth & Orange $585-620 \mathrm{~nm}$ & Brazaityte et al., 2009 \\
\hline Red leaf lettuce (Lactuca sativa L.) 'Banchu Ref & High intensity $\left(300 \mu \mathrm{mol} \cdot \mathrm{m}^{-2} \cdot \mathrm{s}^{-1}\right)$ green LED light & Green $490-550 \mathrm{~nm}$ & Johkan et al., 2012 \\
\hline
\end{tabular}

promoted lettuce growth (as compared to FL); $510 \mathrm{~nm}$ light had the greatest effect on plant growth

Lettuce (Lactuca sativa) cultivars, red leaf 'Sunmang' and green leaf 'Grand Rapid TBR' 18 day seedlings for 4 weeks

The substitution of blue with green LEDs in the presence of a fixed proportion of red enhanced growth of

Green 490-550 nm Son and Oh, 2015 lettuce;

Fresh weights of red leaf lettuce shoots under R8G1B1 were about $61 \%$ higher than those under R8B2

Transplants of cucumber 'Mandy' F1 Accelerated growth

Green 490-550 nm Brazaityte et al., 2009 Supplemental $505 \mathrm{~nm}$ LED light increased leaf area in Green 490-550 nm Samuoliene et al., 2012c all vegetable transplants

'Magnus' F1 and Sweet pepper 'Reda'

Transplants of cucumber 'Mandy' F1

Increased leaf area, decreased hypocotyl elongation Higher B/R ratio (1.0) resulted in shorter stem length Tomato seedlings 'Reiyo'

Cucumber plants (Cucumis sativus cv. Hoffmann's Giganta)

Necessary to prevent any overt dysfunctional photoGreen 490-550 nm Novičkovas et al., 2012 synthesis

Photosynthetic capacity increased with increasing blue percentage during growth measured up to $50 \%$ blue

Cucumber (Cucumis sativus) 'Cumlaude'

Hypocotyl length decreased with increasing blue light up to $75 \%$, and was significantly higher under $100 \%$ blue treatment;

Leaf area decreased with the increase of the percentage of blue up to $75 \% .100 \%$ blue increased leaf area

Seedlings of cabbages (Brasica olearacea var. Promoted petiole elongation in both cabbage varietie

\section{Blue 425-490 nm Nanya et al., 2012}

Blue 425-490 nm Hogewoning et al., 2010 
Table 1 (continued)

\begin{tabular}{|c|c|c|c|}
\hline Plant & Effect on growth & Light colour & Reference \\
\hline $\begin{array}{l}\text { Red leaf lettuce seedlings (Lactuca sativa L. cv. } \\
\text { Banchu Red Fire) }\end{array}$ & $\begin{array}{l}\text { Resulted in compact lettuce seedling morphology; } \\
\text { Promoted the growth of lettuce after transplanting }\end{array}$ & Blue $425-490 \mathrm{~nm}$ & Johkan et al., 2010 \\
\hline $\begin{array}{l}\text { Non-heading Chinese cabbage (Brassica campestris } \\
\text { L.) }\end{array}$ & $\begin{array}{l}\text { Blue LEDs benefit vegetative growth, while red LEDs } \\
\text { and blue plus red LEDs support reproductive growth }\end{array}$ & Blue $425-490 \mathrm{~nm}$ & Li et al., 2012 \\
\hline $\begin{array}{l}\text { Red leaf lettuce (Lactuca sativa } \text { L. cv. } \\
\text { Outeredgeous) }\end{array}$ & Leaf expansion & Blue $425-490 \mathrm{~nm}$ & Stutte et al., 2009 \\
\hline $\begin{array}{l}\text { Lettuce (Lactuca sativa } \text { L. var foliosum cv. } \\
\text { 'Dubacek' and L. sativa L. cv. 'Michalina') }\end{array}$ & Compact plant morphology & Blue $440 \mathrm{~nm}$ & Sergejeva et al., 2018 \\
\hline $\begin{array}{l}\text { Transplants of cucumber hybrid 'Mirabelle' F1, to- } \\
\text { mato hybrid 'Magnus' F1 and sweet pepper 'Reda' }\end{array}$ & $\begin{array}{l}\text { Supplemental blue light increased leaf area in all veg- } \\
\text { etable transplants }\end{array}$ & Blue $425-490 \mathrm{~nm}$ & Samuoliene et al., 2012 \\
\hline Transplants of cucumber 'Mandy' F1 & $\begin{array}{l}\text { Supplemental } 470 \mathrm{~nm} \text { LED lighting increased leaf } \\
\text { area, decreased hypocotyl length; } \\
455 \mathrm{~nm} \text { LED light caused slower growth and develop- } \\
\text { ment of transplants }\end{array}$ & Blue $425-490 \mathrm{~nm}$ & Novickovas et al., 2012 \\
\hline $\begin{array}{l}\text { Cucumber (Cucumis sativus) 'Cumlaude' and to- } \\
\text { mato (Solanum lycopersicum 'Komeett') }\end{array}$ & $\begin{array}{l}\text { Cucumber hypocotyl length decreased with increasing } \\
\text { blue up to } 75 \% \\
\text { Tomato hypocotyl length decreased with increasing } \\
\text { blue up to } 75 \%\end{array}$ & Blue $425-490 \mathrm{~nm}$ & Hernandez et al., 2016 \\
\hline $\begin{array}{l}\text { Cucumber plants (Cucumis sativus cv. Hoffmann's } \\
\text { Giganta) }\end{array}$ & $\begin{array}{l}\text { Necessary to prevent any overt dysfunctional photo- } \\
\text { synthesis } \\
\text { Photosynthetic capacity increased with increasing } \\
\text { blue percentage during growth measured up to } 50 \% \\
\text { blue } \\
\text { Increased in leaf mass per unit leaf area }\end{array}$ & Blue $425-490 \mathrm{~nm}$ & Hogewoning et al., 2010 \\
\hline
\end{tabular}

*PPFD, photosynthetic photon flux density; PP, photoperiod; B, blue; R, red; FR, far red; G, green, FL, fluorescent, WF, white fluorescent, HPS, high pressure sodium

growth in lettuce (Johkan et al., 2012; Son and Oh, 2015). Supplemental green light increased transplant growth of cucumber transplants (Brazaityte et al., 2009; Novickovas et al., 2012; Samuoliene et al., 2012c) and tomato and sweet pepper transplants (Samuoliene et al., 2012c). Blue light resulted in compact lettuce seedlings (Johkan et al., 2010). Blue light promoted petiole elongation in cabbage (Mizuno et al., 2011). Decreased hypocotyl length in cucumber transplants was observed under blue light (Novickovas et al., 2012; Hernandez et al., 2016; Hernandez and Kubota, 2016). Blue light accelerated leaf expansion in lettuce, and in tomato, cucumber and sweet pepper transplants (Stutte et al., 2009; Novickovas et al., 2012; Samuoliene et al., 2012c; Hernandez and Kubota, 2016). Tomato seedlings had shorter stem length under blue light (Nanya et al., 2012). In non-heading Chinese cabbage blue light benefitted vegetative growth, while blue light in combination with red light supported reproductive growth (Li et al., 2012).

\section{YIELD OF VEGETABLES INFLUENCED BY DIFFER- ENT LIGHT COLOURS}

Greenhouse vegetable yield is influenced by different light colours (Table 2). Fresh weight of lettuce, baby leaf lettuce and red leaf lettuce was observed to increase under additional far red lighting ( $\mathrm{Li}$ and Kubota, 2009; Stutte et al, 2009; Lee et al., 2015; Chen et al., 2016; Lee et al., 2016; Pinho et al., 2017).

Red light enhanced tomato yield (Lu et al., 2012). In addition to effect of red light, green light increased lettuce fresh weight (Son and Oh, 2015). Similar effects on fresh weight of cucumber transplants were obtained by Novickovas et al. (2012) and Samuoliene et al. (2012c). Blue light stimulated biomass accumulation in red leaf lettuce seedlings (Johkan et al., 2010). Increased fresh weight was obtained in coriander under blue light (Naznin et al., 2016). In contrast, blue light decreased shoot dry weight in Chinese kale (Xin et al., 2015). All spectra combined with additional blue light increased fresh weight of cucumber transplants (Novickovas et al., 2012; Samuoliene et al., 2012c). Similarly, all spectra plus additional blue light increased fresh weight of cucumber and tomato transplants (Hernandez and Kubota, 2016, Menard et al., 2006) but decreased fruit yield (Menard et al., 2006).

UVA light increased fresh weight in lettuce (Chang and Chang, 2014).

\section{NUTRITIONAL QUALITY}

Greenhouse vegetables nutritional quality is influenced by different light colours (Table 3).

Vitamin C concentration. Vitamin C concentration in mustard, spinach, rocket, dill and green onion was observed to increase due to exposure to red light (Bliznikas et al., 2012). Lower concentration of C-vitamin occurred under red light in Lamb's lettuce and green baby leaf lettuce (Samuoliene et al., 2012a; Wojciechowska et al., 2015). Green light increased vitamin $\mathrm{C}$ concentration in different types of lettuce (Samuoliene et al., 2012b). Blue light in- 
THE EFFECT OF LIGHT COLOUR ON YIELD OF GREENHOUSE VEGETABLES

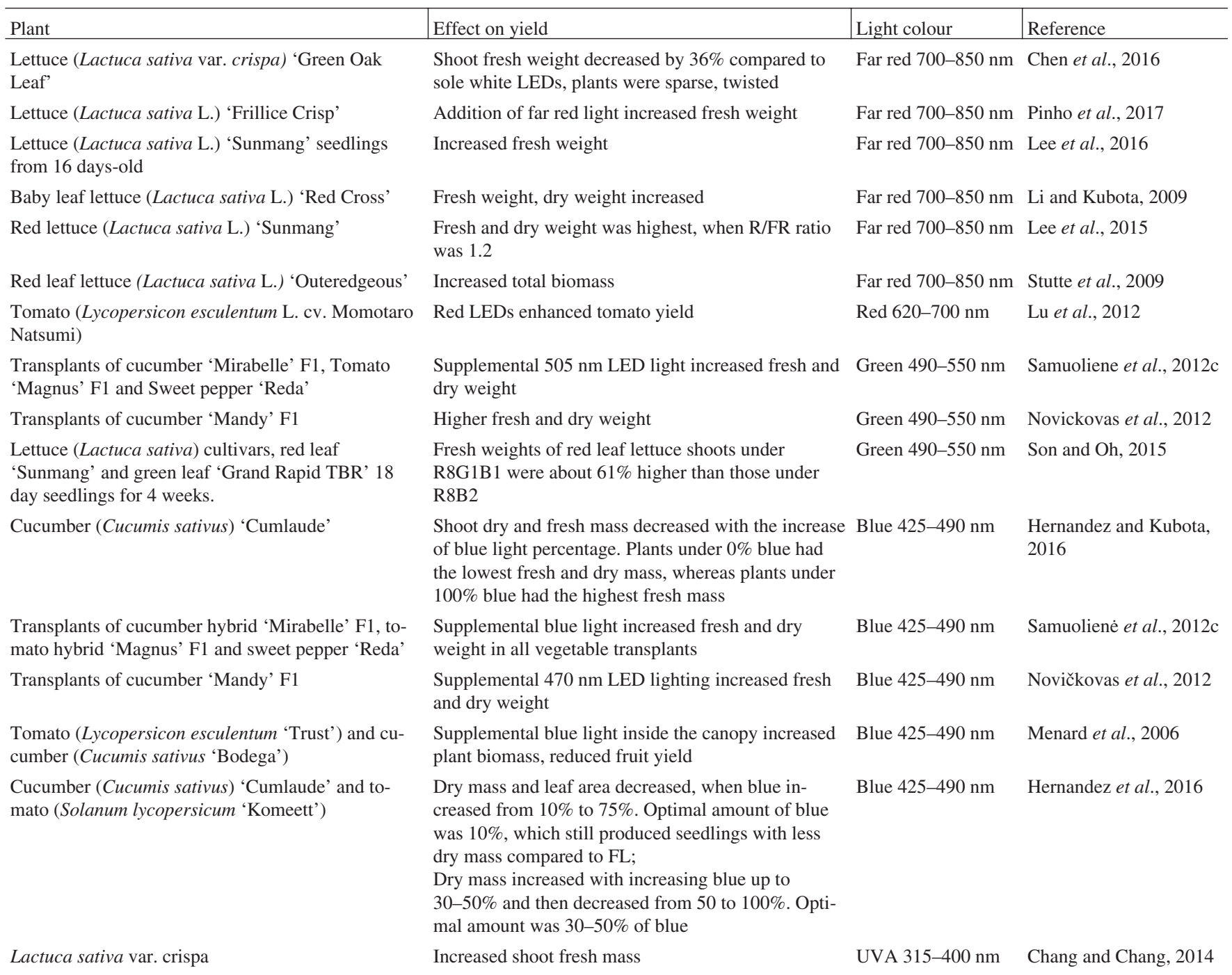

*PPFD, photosynthetic photon flux density; PP, photoperiod; B, blue; R, red; FR, far red; G, green, FL, fluorescent, WF, white fluorescent, HPS, high pressure sodium

creased vitamin $\mathrm{C}$ concentration in non-heading Chinese cabbage (Li et al., 2012).

Mineral elements. Far red light stimulated uptake of $\mathrm{N}$ and $\mathrm{K}, \mathrm{Ca}$, and $\mathrm{Mg}$ with the latter increasing by $27 \%, 25 \%$, and $28 \%$, respectively, compared to plants illuminated with red and blue light (Pinho et al., 2017). Blue light increased $\mathrm{N}$ concentration in cucumber plants (Hogewoning et al., 2010) but reduced nitrate concentration in Chinese kale (Xin et al., 2015). Green light decreased nitrate concentration in butterhead lettuce and baby leaf lettuce (Bian et al., 2016; Samuoliene et al., 2012d).

Pigments. Far red light decreased chlorophyll and carotenoid concentration in baby leaf lettuce ( $\mathrm{Li}$ and Kubota, 2009). Red light increased chlorophyll concentration in lettuce and kale (Lefsrud et al., 2008; Chen et al., 2016). Red light increased carotenoid concentration of lettuce (Chen et al., 2016) and anthocyanin concentration of cabbage (Mizuno et al., 2011). Total carotenoid concentration in mus- tard and parsley increased, and in pak choi and tatsoi decreased, due to exposure to green light in addition to all other spectra (Brazaityte et al., 2016). Green light supplemental to all other spectra increased pigment concentration of cucumber, tomato and sweet pepper transplants (Samuoliene et al., 2012c). Blue light resulted in enhanced chlorophyll concentration of cabbage seedlings, in non-heading Chinese cabbage and cucumber transplants (Hogewoning et al., 2010; Mizuno et al., 2011; Li et al., 2012). Blue light increased anthocyanin concentration in baby leaf and red leaf lettuce (Li and Kubota, 2009; Stutte et al., 2009). Carotene concentration increased under blue light in baby leaf lettuce and in kale (Lefsrud et al., 2008; Li and Kubota, 2009). Blue light supplemental to all other spectra increased pigment concentration in cucumber, tomato and sweet pepper transplants, lettuce (Novickovas et al., 2012; Samuoliene et al., 2012c; Sergejeva et al., 2018). UVA and UVB light increased anthocyanin concentration in lettuce and baby leaf lettuce (Li and Kubota, 2009; Goto et al., 2016). 
EFFECT OF LIGHT COLOUR ON NUTRITIONAL QUALITY OF GREENHOUSE VEGETABLES

\begin{tabular}{l|l|l|l}
\hline Nutrient & Plant & Effect & Light colours \\
\hline Antioxidant & $\begin{array}{l}\text { Lamb's lettuce (Valerianella locusta } \text { L.) } \\
\text { 'Nordhollandse' }\end{array}$ & Reduced ascorbic acid concentration & Red 620-700 nm \\
& $\begin{array}{l}\text { Green baby leaf lettuce (Lactuca sativa } \text { L.) } \\
\text { 'Thumper' and 'Multibaby' }\end{array}$ & $\begin{array}{l}\text { Increased antioxidant properties in } \\
\text { 'Multibaby' lettuce: higher concentration of }\end{array}$ & Red 620-700 nm \\
& Samuolienè et al., 2012a
\end{tabular}

total phenolic $(28.5 \%)$, tocopherols $(33.5 \%)$ antioxidant capacity $(14.5 \%)$ and sugars $(52.0 \%)$

Decreased concentration of ascorbic acid, as compared to untreated plants

White mustard (Sinapsis alba) 'Yellow musAltered antioxidant activity. Increase in vita- Red 620-700 nm min $\mathrm{C}$ content in mustard, spinach, rocket, tard', Spinach (Spinacia oleracea) 'Giant
d'hiver', Rocket (Eruca sativa) 'Rucola', Dill dill and green onion (Anethum graveolens) 'Mammouth', Parsley (Petroselinum crispum) 'Plain leaved', Green onions (Allium cepa) 'White Lisbon'

Red leaf 'Multired 4', green leaf 'Multigreen 3' and light green leaf 'Multiblond 2' baby leaf lettuce (Lactuca sativa L.)

$535 \mathrm{~nm}$ green LEDs had greater positive effect on ascorbic acid, tocopherol contents and DPPH free-radical scavenging capacity

Red leaf lettuce seedlings (Lactuca sativa L. cv. Banchu Red Fire)

Greater polyphenol concentrations and total antioxidant status

Non-heading Chinese cabbage (Brassica campestris L.)

Minerals Lettuce (Lactuca sativa L.) 'Frillice Crisp'

Concentration of vitamin $\mathrm{C}$ was the greatest under blue LEDs

Far red light stimulated the uptake of N;

The uptake of $\mathrm{K}, \mathrm{Ca}$ and $\mathrm{Mg}$ by plants under additional far red light increased by $27 \%$, $25 \%$ and $28 \%$, respectively, as compared to plants, illuminated with red and blue light

Cucumber plants (Cucumis sativus cv. Hoffmann's Giganta)

Butterhead lettuce 'De Lier' Increase in nitrogen concentration per area

Baby leaf lettuce: red leaf 'Multired 4', green leaf 'Multigreen 3' and light green leaf

Decreased nitrate concentrations 'Multiblond 2'

Chinese kale 'Lybao'

Pigments Baby leaf lettuce (Lactuca sativa L.) 'Red Cross'

Reduced nitrate concentration in all baby leaf lettuce varieties

Reduced nitrate concentration at higher blue light rates

Decreased chlorophyll and carotenoid concentration by $14 \%$ and $11 \%$ as compared to WF

Cabbages (Brasica olearacea var. capitata

L.) 'Kinshun' (green leaves) and 'Red Rookie' (red leaves)

Increased anthocyanin contents and leaf pig mentation in red leaf cabbages comparing to FL, 470-, 500-, 525 nm LEDs

Lettuce (L. sativa var. crispa) 'Green Oak

Leaf'

Increased chlorophyll and carotenoids concentrations

Kale (Brassica oleracea L). 'Winterbor'

Various microgreens

Enhanced chlorophyll $a, b$ accumulation

Increased total carotenoids in mustard and parsley microgreens;

Decreased total carotenoids in red pak choi and tatsoi microgreens

Transplants of cucumber 'Mirabelle' F1, Tomato 'Magnus' F1 and Sweet pepper 'Reda'

Supplemental $505 \mathrm{~nm}$ LED light increased photosynthetic pigment concentrations in all vegetable transplants Supplemental $530 \mathrm{~nm}$ light had positive effect on development and photosynthetic pigment accumulation in cucumber transplants

Cucumber plants (Cucumis sativus cv. Increased chlorophyll concentration per area Hoffmann's Giganta)

Transplants of cucumber hybrid 'Mirabelle' F1, tomato hybrid 'Magnus' F1 and sweet pepper 'Reda'

Supplemental blue light increased photosynthetic pigment concentrations in all vegetable transplants

Transplants of cucumber 'Mandy' F1

Both 455 and $470 \mathrm{~nm}$ enhanced photosynthetic pigment concentrations

Blue 425-490 nm Hogewoning et al., 2010

Green 490-550 nm Bian et al., 2016

Green 490-550 nm Samuoliene et al., 2012b

Blue 425-490 nm

Johkan et al., 2010

Blue 425-490 nm Li et al., 2012

Far red 700-850 nm Pinho et al., 2017

Green 490-550 nm Samuoliene et al., 2012d

Blue $425-490 \mathrm{~nm}$

Xin et al., 2015

Far red 700-850 nm Li and Kubota, 2009

Red 620-700 nm

Mizuno et al., 2011

Red 620-700 nm

Chen et al., 2016

Red 620-700 nm

Lefsrud et al., 2008

Green 490-550 nm Brazaityte et al., 2016

Green 490-550 nm Samuoliene et al., 2012c

Blue $425-490 \mathrm{~nm}$

Hogewoning et al., 2010

Blue 425-490 nm Samuoliene et al., 2012c

Blue 425-490 nm Novickovas et al., 2012 
Table 3 (continued)

\begin{tabular}{|c|c|c|c|c|}
\hline Nutrient & Plant & Effect & Light colours & Reference \\
\hline & $\begin{array}{l}\text { Baby leaf lettuce (Lactuca sativa } \mathrm{L} . \text {.) 'Red } \\
\text { Cross' }\end{array}$ & $\begin{array}{l}\text { Anthocyanins concentration increased by } \\
31 \% \text {; } \\
\text { Carotenoids concentration increased by } 12 \%\end{array}$ & Blue $425-490 \mathrm{~nm}$ & Li and Kubota, 2009 \\
\hline & $\begin{array}{l}\text { Seedlings of cabbages (Brasica olearacea } \\
\text { var. capitata L.) 'Kinshun' (green leaves) and } \\
\text { 'Red Rookie' (red leaves) }\end{array}$ & $\begin{array}{l}\text { Higher chlorophyll concentrations in green } \\
\text { leaf cabbages }\end{array}$ & Blue $425-490 \mathrm{~nm}$ & Mizuno et al., 2011 \\
\hline & $\begin{array}{l}\text { Kale plants (Brassica oleracea L. cv } \\
\text { Winterbor) }\end{array}$ & Enhanced $\beta$-carotene concentration & Blue $425-490 \mathrm{~nm}$ & Lefsrud et al., 2008 \\
\hline & $\begin{array}{l}\text { Lettuce (Lactuca sativa L. var. foliosum cv. } \\
\text { 'Dubacek' and L. sativa L. cv. 'Michalina') }\end{array}$ & Increased chlorophyll concentration & Blue $440 \mathrm{~nm}$ & Sergejeva et al., 2018 \\
\hline & $\begin{array}{l}\text { Red leaf lettuce (Lactuca sativa L. cv. } \\
\text { Outeredgeous) }\end{array}$ & $\begin{array}{l}\text { Increased concentration of anthocyanins, } \\
\text { higher antioxidant potential }\end{array}$ & Blue $425-490 \mathrm{~nm}$ & Stutte et al., 2009 \\
\hline & Lettuce (Lactuca sativa L.) 'Red fire' & $\begin{array}{l}\text { Pre-harvest UV-B light stimulated } \\
\text { anthocyanin concentration } \\
\text { Anthocyanin concentration was significantly } \\
\text { higher at } 310 \mathrm{~nm} \text { as compared to } 325 \text { and } 340 \\
\mathrm{~nm}\end{array}$ & $\begin{array}{l}\text { UVA } 315-400 \mathrm{~nm} \\
\text { and UVB } 280-315 \\
\mathrm{~nm}\end{array}$ & Goto et al., 2016 \\
\hline \multirow[t]{3}{*}{ Sugars } & $\begin{array}{l}\text { Dill (Anethum graveolens) 'Mammouth', } \\
\text { Parsley (Petroselinum crispum) 'Plain } \\
\text { leaved' }\end{array}$ & Increased monosaccharide concentration & Red 620-700 nm & Bliznikas et al., 2012 \\
\hline & $\begin{array}{l}\text { Baby leaf lettuce: red leaf 'Multired 4', green } \\
\text { leaf 'Multigreen 3' and light green leaf } \\
\text { 'Multiblond 2' }\end{array}$ & $\begin{array}{l}\text { Increase in saccharide concentrations in all } \\
\text { baby leaf lettuce varieties }\end{array}$ & Green $490-550$ nm & Samuoliene et al., 2012d \\
\hline & Chinese kale 'Lybao' & Increased soluble sugar concentration & Blue $425-490 \mathrm{~nm}$ & Xin et al., 2015 \\
\hline
\end{tabular}

*PPFD, photosynthetic photon flux density; PP, photoperiod; B, blue; R, red; FR, far red; G, green, FL, fluorescent, WF, white fluorescent, HPS, high pressure sodium

Sugars. Red light increased monosaccharide concentration of dill and parsley (Bliznikas et al., 2012). Green light increased saccharide concentration in baby leaf lettuce (Samuoliene et al., 2012d). Blue light increased soluble sugar concentration in Chinese kale, and the combinations red $:$ blue $=8: 1(8 \mathrm{R} 1 \mathrm{~B})$, red $:$ blue $=6: 3(6 \mathrm{R} 3 \mathrm{~B})$ and 6R3B gave higher soluble sugar concentration (Xin et al., 2015).

\section{PRACTICAL CONCLUSIONS}

Fresh weight of leafy vegetable crops and transplants can be increased by increasing by supplemental green light, far red light (while can be accompanied with elongation of plants) and in some cases with UVA light. Increases of fruiting crops yield can be achieved by supplemental red light, and decreases by blue light.

Growth of leafy vegetables crops and transplants are increased by added green light, blue light (leaf expansion, while can be accompanied with compactness of plants, which is desirable in most of cases), far red light (while can be accompanied with elongation of plants) and orange light.

Vitamin $\mathrm{C}$ concentration is increased under green and blue light. The concentration of nitrates in plants is decreased under blue and green light. The pigment concentration in plants is increased under green, blue and red light. Sugar contents in plants are increased by green, blue and red light.

As plant elongation and decrease in pigment concentration are not desirable, far red light should not be used to increase biomass. As red light increases yield by decreasing nitrate content and increasing $\mathrm{C}$-vitamin content, and considering that both factors are highly desirable, then this colour has big potential use in plant production. Orange light accelerates growth of transplants, and therefore this light colour is also desirable in plant production. As green light contributes to only desirable factors (promotes growth, reduces nitrate concentration, increases saccharide concentration of plants, and increases vitamin C concentration in plants), then green light is desirable in plant production and has also big potential use in plant production. As blue light contributes to desirable factors only (results in compact plants, benefits vegetative growth, increases pigment and vitamin $\mathrm{C}$ concentration in plants), then green light is desirable in plant production and has also big potential use in plant production.

\section{FINAL CONCLUSION}

Based on the given information we can conclude that blue, green, and red light are the main light colours that influence positively plant yield, growth and nutrient quality. Some- 
times in specific situations some other light colours are also beneficial, like far red light, orange light and UVA light. Future work on light colour manipulation has potential for producing lamps and greenhouse covers that better support plant yield, growth and nutrition.

\section{REFERENCES}

Anonymous. (1992). Solar and Ultraviolet Radiation. IARC Monographs, Lyon, France.

Anonymous. (2012). Which regions of the electromagnetic spectrum do plants use to drive photosynthesis? Heliospectra. Available at: www.heliospectra.com (accessed 15.06.2016)

Bian, Z. H., Cheng, R. F., Yang, Q. C., Wang, J. Lu, C. (2016). Continuous light from red, blue, and green light-emitting diodes reduces nitrate content and enhances phytochemical concentrations and antioxidant capacity in lettuce. J. Amer. Soc. Horticult. Sci., 141 (2), 186-195.

Bliznikas, Z., Žukauskas, A., Samuoliene, G., Viršile, A., Brazaityte, A., Jankauskiene, J, Duchovskis, P., Novičkovas, A. (2012). Effect of supplementary pre-harvest LED lighting on the antioxidant and nutritional properties of green vegetables. Acta Horticult., 939, 85-91.

Brazaitytė, A., Duchovskis, P., Urbonavičiūtè, A., Samuolienė, G., Jankauskienė, J., Kasiulevičiūtė-Bonakèrè, A., Bliznikas, Z., Novičkovas, A., Breivè, K., Žukauskas, A. (2009). The effect of light-emitting diodes lighting on cucumber transplants and after-effect on yield. Zemdirbyste-Agriculture, 96 (3), 102-118.

Brazaitytė, A., Virsilè, A., Samuolienè, G., Jankauskienė, J., Sakalauskienè, S., Sirtautas, R., Novičkovas, A., Dabašinskas, L., Vaštakaitè, V., Miliauskienè, J., Duchovskis, P. (2016). Light quality: Growth and nutritional value of microgreens under indoor and greenhouse conditions. Acta Horticult., 1134, 277-284.

Brown, C. S., Schuerger, A. C., Sager, J. C. (1995). Growth and photomorphogenesis of pepper plants under red light-emitting diodes with supplemental blue or far-red lighting. J. Amer. Soc. Horticult. Sci., 120 (5), $808-813$

Chang, C. L., Chang, K. P. (2014). The growth response of leaf lettuce at different stages to multiple wavelength-band light-emitting diode lighting. Sci. Horticult., 179, 78-84.

Chen, X. L., Xue, X. Z., Guo, W. Z., Wang, L. C., Qiao, X. J. (2016). Growth and nutritional properties of lettuce affected by mixed irradiation of white and supplemental light provided by light-emitting diode. Sci. Horticult., 200, 111-118.

D'Souza, C., Yuk, H. G., Khoo, G. H., Zhou, W. (2015). Application of light-emitting diodes in food production, postharvest preservation, and microbiological food safety. Compreh. Revi. Food Sci. Food Safety, 14 (6), 719-740.

Goto, E., Hayashi, K., Furuyama, S., Hikosaka, S., Ishigami, Y. (2016). Effect of UV light on phytochemical accumulation and expression of anthocyanin biosynthesis genes in red leaf lettuce. Acta Horticult., 1134, $179-186$.

Hernández, R., Eguchi, T., Kubota, C. (2016). Growth and morphology of vegetable seedlings under different blue and red photon flux ratios using light-emitting diodes as sole-source lighting. Acta Horticult., 1134, $195-200$

Hernández, R., Kubota, C. (2016). Physiological responses of cucumber seedlings under different blue and red photon flux ratios using LEDs. Environ. Exper. Bot., 121, 66-74.

Hogewoning, S. W., Trouwborst, G., Maljaars, H., Poorter, H., van Ieperen, W., Harbinson, J. (2010). Blue light dose-responses of leaf photosynthesis, morphology, and chemical composition of Cucumis sativus grown under different combinations of red and blue light. J. Exper. Bot., 61 (11), 3107-3117.
Johkan, M., Shoji, K., Goto, F., Hashida, S. N., Yoshihara, T. (2010). Blue light-emitting diode light irradiation of seedlings improves seedling quality and growth after transplanting in red leaf lettuce. HortScience, 45 (12), 1809-1814.

Johkan, M., Shoji, K., Goto, F., Hahida, S. N., Yoshihara, T. (2012). Effect of green light wavelength and intensity on photomorphogenesis and photosynthesis in Lactuca sativa. Environ. Exper. Bot., 75, 128-133.

Lee, M. J., Park, S. Y., Oh, M. M. (2015). Growth and cell division of lettuce plants under various ratios of red to far-red light-emitting diodes. Horticult. Environ. Biotechnol., 56 (2), 186-194.

Lee, M. J., Son, K. H., Oh, M. M. (2016). Increase in biomass and bioactive compounds in lettuce under various ratios of red to far-red LED light supplemented with blue LED light. Horticult. Environ. Biotechnol., 57 (2), $139-147$.

Lefsrud, M. G., Kopsell, D. A., Sams, C. E. (2008). Irradiance from distinct wavelength light-emitting diodes affect secondary metabolites in kale. HortScience, 43 (7), 2243-2244.

Li, Q., Kubota, C. (2009). Effects of supplemental light quality on growth and phytochemicals of baby leaf lettuce. Environ. Exper. Bot., 67 (1), $59-64$

Li, H., Tang, C., Xu, Z., Liu, X., Han, X. (2012). Effects of different light sources on the growth of non-heading Chinese cabbage (Brassica campestris L.). J. Agricult. Sci., 4 (4), 262-273.

Lu, N., Maruo, T., Johkan, M., Hohjo, M., Tsukagoshi, S., Ito, Y., Ichimura, T., Shinohara, Y. (2012). Effects of supplemental lighting with light-emitting diodes (LEDs) on tomato yield and quality of single-truss tomato plants grown at high planting density. Environ. Control Biol., 50 (1), 63-74.

Ménard, C., Dorais, M., Hovi, T., Gosselin, A. (2006). Developmental and physiological responses of tomato and cucumber to additional blue light. Acta Horticult., 711, 291-296.

Mizuno, T., Amaki, W., Watanabe, H. (2011). Effects of monochromatic light irradiation by LED on the growth and anthocyanin contents in leaves of cabbage seedlings. Acta Horticult., 907, 179-184.

Morrow, R. C. (2008). LED lighting in horticulture. HortScience, 43, $1947-1950$

Nanya, K., Ishigami, Y., Hikosaka, S., Goto, E. (2012). Effects of blue and red light on stem elongation and flowering of tomato seedlings. Acta Horticult., 956, 261-266.

Naznin, M. T., Lefsrud, M., Gravel, V., Hao, X. (2016). Different ratios of red and blue LED light effects on coriander productivity and antioxidant properties. Acta Horticult., 1134, 223-230.

Novickovas, A., Brazaitytė, A., Duchovskis, P., Jankauskienė, J., Samuolienè, G., Virsilè, A., Sirtautas, R., Bliznikas, Z., Zukauskas, A. (2012). Solid-state lamps (LEDs) for the short-wavelength supplementary lighting in greenhouses: Experimental results with cucumber. Acta Horticult., 927, 723-730.

Olle, M., Viršile, A. (2013). The effects of light-emitting diode lighting on greenhouse plant growth and quality. Agricult. Food Sci., 22 (2), 223-234.

Ouzounis, T., Heuvelink, E., Ji, Y., Schouten, H. J., Visser, R. G. F., Marcelis, L. F. M. (2016). Blue and red LED lighting effects on plant biomass, stomatal conductance, and metabolite content in nine tomato genotypes. Acta Horticult., 1134, 251-258.

Pinho, P., Jokinen, K., Halonen, L. (2017). The influence of the LED light spectrum on the growth and nutrient uptake of hydroponically grown lettuce. Lighting Res. Technol., 49 (7), 866-881.

Rajapakse, N. C., Young, R. E., McMahon, M. J. and Oi, R., (1999). Plant height control by photoselective filters: Current status and future prospects. HortTechnology, 9 (4), pp. 618-624.

Ryer, A. (1998). What is light? Light Measurement Handbook. International Light Inc., Newburyport, USA. 942 pp. 
Samuolienė, G., Urbonavičiūtė, A., Duchovskis, P., Bliznikas, Z., Vitta, P., Žukauskas, A. (2009). Decrease in nitrate concentration in leafy vegetables under a solid-state illuminator. HortScience, 44 (7), 1857-1860.

Samuolienè, G., Brazaitytė, A., Sirtautas, R., Novičkovas, A., Duchovskis, P. (2011). Supplementary red-LED lighting affects phytochemicals and nitrate of baby leaf lettuce. J. Food Agricult. Environ., 9 (3-4), 271-274.

Samuolienė, G., Brazaitytė, A., Duchovskis, P., Viršilè, A., Jankauskienė, J., Sirtautas, R, Samuolienè, G., Sirtautas, R., Brazaitytė, A., Viršilè, A., Duchovskis, P. (2012a). Supplementary red-LED lighting and the changes in phytochemical content of two baby leaf lettuce varieties during three seasons. J. Food Agricult. Environ., 10 (10), 701-706.

Samuolienè, G., Sirtautas, R., Brazaitytė, A., Duchovskis, P. (2012b). LED lighting and seasonality effects antioxidant properties of baby leaf lettuce. Food Chem., 134 (3), 1494-1499.

Samuolienė, G., Brazaitytė, A., Duchovskis, P., Viršilè, A., Jankauskienė, J., Sirtautas, R., Novičkovas, A., Sakalauskienè, S., Sakalauskaitė, J. (2012c). Cultivation of vegetable transplants using solid-state lamps for the short-wavelength supplementary lighting in greenhouses. Acta Horticult., 952, 885-892.

Samuolienè, G., Brazaitytė, A., Sirtautas, R., Novičkovas, A., Duchovskis, P. (2012d). The effect of supplementary LED lighting on the antioxidant and nutritional properties of lettuce. Acta Horticult., 952, 835-841.
Sergejeva, D., Alsina, I., Duma, M., Dubova, L., Augspole, I., Erdberga, I. Berzina, K. (2018). Evaluation of different lighting sources on the growth and chemical composition of lettuce. Agron. Res., 16 (3), 892-899.

Son, K. H., Oh, M. M. (2015). Growth, photosynthetic and antioxidant parameters of two lettuce cultivars as affected by red, green, and blue light-emitting diodes. Horticult. Environ. Biotechnol., 56 (5), 639-653.

Stapleton, A. E., 1992. Ultraviolet radiation and plants: Burning questions. The Plant Cell, 4 (11), 1353-1358.

Stutte, G. W., Edney, S., Skerritt, T. (2009). Photoregulation of bioprotectant content of red leaf lettuce with light-emitting diodes. HortScience, 44 (1), 79-82.

Tarakanov, I., Yakovleva, O., Konovalova, I., Paliutina, G., Anisimov, A. (2012). Light-emitting diodes: On the way to combinatorial lighting technologies for basic research and crop production. Acta Horticult., 956, 171-178.

Wojciechowska, R., Długosz-Grochowska, O., Kołton, A., Żupnik, M. (2015). Effects of LED supplemental lighting on yield and some quality parameters of lamb's lettuce grown in two winter cycles. Scientia Horticult., 187, 80-86.

Xin, J., Liu, H., Song, S., Chen, R., Sun, G. (2015). Growth and quality of Chinese kale grown under different LEDs. Agricult. Sci. Technol., 16 (1), 68-115.

\section{GAISMAS VIL,N̦U GARUMA IETEKME UZ SILTUMNĪCĀ AUDZĒTU DĀRZEN̦U AUGŠANU, RAŽU UN BARĪBAS VIELU SATURU}

Vairumā zinātnisko apskatrakstu tiek analizēta gaismas spektrālā sastāva ietekme uz augu ražu un kvalitāti, bet tādu, kur apkopota informācija par noteiktu gaismas spektra daḷu ietekmi uz cukuru vai pigmentu saturu, augšanas un/vai attīstības regulēšanas iespējām, ir ḷoti maz. Redzamās gaismas loma tādās pārtikas ražošanas nozarēs kā laukkopība un dārzkopība ir vispārzināma, jo gaisma ir fotosintēzes procesu enerǵētiskais pamats, kas nosaka augu augšanu un attīstību. Salīdzinot ar plaši izmantotajām gāzizlādes vai nātrija lampām, gaismu emitējošās diodes (LED) ir būtiski atškirīga tehnoloğija. LED lampas ir apgaismojuma veids, kura apgaismojuma spektrālo sastāvu var mainīt, lai nodrošinātu dažādos augu augšanas un attīstības posmos nepieciešamo apgaismojuma kvantitatīvo un kvalitatīvo sastāvu. Neraugoties uz to, ka veikti daudzi un dažādi eksperimenti, lai noskaidrotu, kā dažādi gaismas viḷnu garumi ietekmē siltumnīcā audzētu dārzeṇu ražas veidošanos, maz ir zināms par fizioloğiskajiem mehānismiem, kas ietekmē cukuru vai pigmentu saturu, kā arī ražas pieaugumu. Šajā rakstā apskatīts, kā noteikts gaismas spektrālais diapazons ietekmē siltumnīcas dārzeņu augšanu, ražu un to uzturvērtību. Pamatojoties uz iegūto informāciju, var secināt, ka zila, zaḷa un sarkana gaisma ir galvenās augu ražu, augšanu un uzturvērtību pozitīvi ietekmējošās spektra daḷas. Atsevišḳās situācijās novēro arī citu spektra daḷu (tālā sarkanā, oranžā un UVA) pozitīvo ietekmi. Turpmākie gaismas spektrālā sastāva ietekmes pētījumi ir nozīmīgi, jo tie veicinās lampu un siltumnīcu segumu pilnveidošanu, tādējādi uzlabojot augu augšanu, ražu un tās kvalitāti. 